\title{
Garbage Pollution In The Cisadane River In The Tangerang Region
}

\author{
Hinijati Widjaja ${ }^{1}$, Alicia Wellsan ${ }^{2}$, Gabriella Mistissy ${ }^{3}$, N.Dhea Madinah Al Qibthia ${ }^{4}$, Febri \\ Yenny $^{5}$, Olivia Dais Agustin ${ }^{6}$ \\ \{hinijati@trisakti.ac.id ${ }^{1}$, aliciawellsan@gmail.com², gmistissy@gmail.com ${ }^{3}$, dhea.mdh@gmail.com ${ }^{4}$, \\ febry.atha@gmail.com ${ }^{5}$,daisolivia@gmail.com ${ }^{6}$ \}
}

Trisakti University, Jalan. Kyai Tapa No. 1 Jakarta Barat-Indonesia, 1,2,3,4,5,6

\begin{abstract}
The Cisadane River that crosses the Tangerang, Banten Province every year is estimated to hold around 14-17 tons of garbage entering from residential areas along the river flow, and which is carried by the flow of water from its head on the slopes of Mount Pangrango and Mount Salak in Bogor, West Java. The influx of large volumes of garbage has disrupted the function of the river as a source of raw water and flood control. The purpose of this study was to determine the impact of the spread of garbage on the Cisadane River. The volume of waste from 13 sub-districts in the Tangerang Region, in August 2018, usually 14 tons to 17 tons. This condition is made worse by the presence of rubbish carried by the flow of water from Bogor and South Tangerang Regencies. Based on 2015 BPS data, the area of residential areas is $61 \%, 18 \%$ rice fields and $17 \%$ airports. So it can be understood if floods always occur in several areas of the City of Tangerang, one of which is due to the river flow is not smooth. This research concludes that garbage has caused siltation on the edges, bodies and river banks, consequently disrupting the flow of water and decreasing the function of the Cisadane River. Areas that are easily affected by flooding such as Karawaci Subdistrict, Priuk Subdistrict, Neglasari Subdistrict, Curug Subdistrict, Kosambi Subdistrict, Mekar Kondang Subdistrict, Paku Haji Subdistrict, Sindang Jaya Subdistrict, Sindang Jaya Subdistrict, Teluk Naga Subdistrict
\end{abstract}

Keywords: Cisadane River, Tangerang, waste, environment

\section{Introduction}

\subsection{Background}

The average area of Kota Tangerang is at an altitude of 10-18 meters above sea level. The North has an average height of 10 meters above sea level, while the South has a height of 18 meters above sea level. Judging from the slope of the land, most of the City of Tangerang has a land slope of 0-3\%. Cisadane River which has an average water discharge of $88 \mathrm{~m} 3$ per second and flows as far as $15 \mathrm{Km}$. In the city of Tangerang there are also waterways which include the Mokevart Canal, the Tanah Tinggi Main Irrigation Canal, the West Cisadane Main Canal, the East Cisadane Main Canal, and the North Cisadane Main Canal [7]. Irrigation 
channels that cross the city of Tangerang are 16 channels with a total length reaching $62,488.30$ $\mathrm{Km}$.

The existence of the Cisadane River divides Tangerang City into two parts, namely the East and West parts of the river. The flow of large and small rivers is very beneficial for the supply of clean water raw materials, for the development of clean water installations of the Tangerang City Water Supply Company (PDAM). The surface water supply can also be used for the water needs of industrial activities and the household needs of people who live in river environments. In the planning of the area and the city including the arrangement of the river which is done always try to be able to integrate the life of the city community with the existence of the river. The relationship between the river and the city is a step that must be studied because the behavior (culture) and the restoration step are often not integrated and cause conflict [11].

Based on the General Characteristics of the Cisadane River Basin, it is a natural ecosystem that has a variety of functions for various populations. There are those who use the river as a source of raw water, irrigation, toilet washing needs (MCK), recreation, as well as green open space $(\mathrm{RTH})$. The river problem discussed in this review is the Cisadane River, which is a River Basin (DAS) in Banten Province which is tipped in the Bogor region, West Java, has a length of $139 \mathrm{~km}$. As for the flow that crosses the city of Tangerang, has a catchment area of $1,411 \mathrm{~km} 2$ [8], but with the problem of household waste entering water bodies due to the attitude of the community around the banks of the Cisadane River who do not care and do not understand the importance of a river.

In Article 1 Paragraph (5) Government Regulation No. 38 of 2011: concerning Rivers, it has been described that: "A watershed is a land area which is an integral part of the river and its tributaries, whose function is to collect, store and drain the water originating from rainfall to lakes or to the sea naturally where land boundaries are topographical separators and sea boundaries to waters that are still affected by land activities "[2],[11]. The function of the river ecosystem is very important for the availability of water resources [6],[10]. However, almost all of the river basins in urban areas in Indonesia have been damaged. Industrialization and trade exploit large-scale rivers for waste disposal and unfortunately increasingly damage the value of these ecosystems (Lerner and Holt, 2012) [9]. Most of the damage that occurs to rivers is caused by human activities that dispose of household waste, hotel waste and factory waste in watersheds. All kinds of rubbish and waste are discharged into the watershed without any prior treatment so that the river water is polluted. 


\subsection{Problems}

Regarding the inclusion of garbage on the surface of the river, it can disrupt the function of the Cisadane River as flood control for the entire Tangerang Region. Besides the impact of waste can reduce water capacity and this is detrimental, because the river is one of the surface water sources that are often used by communities around the banks of the Cisadane river.

\subsection{Purpose}

This research was conducted with the aim to find out the problems that pollute the function of the Cisadane River, so it needs to be investigated to what extent the influence of the entry of garbage into the river

\section{Methodology}

This research was started directly by means of grounded, using a qualitative descriptive method approach with the type of research used in this study is the Empirical approach method, namely that in analyzing this problem carried out with primary data obtained from the field, taking into account the volume of waste entering the body river water in the Tangerang region from the Cisadane river environment situation.

For the implementation of research carried out in a qualitative naturalistic manner, as is in the field, with conditions occurring naturally and in normal situations, which are not manipulated in their circumstances. In addition, literature studies, field observations and interviews with garbage cleaners and a number of communities that live around the riverbank are conducted.

\subsection{Time and Place}

The study was conducted from the 1st to the 25th June 2018, along the banks of the Cisadane River in the City of Tangerang (Neglasari District) and Tangerang District (Paku Haji District).

\subsection{Data}

The source of research data is to use primary data (direct observation, for events, the condition of waste in water bodies), the condition of riverbanks and the attitude of the people living around the river. Secondary data obtained from the Tangerang City Regulation No. 10 of 2014 concerning the Medium-term Regional Development Plan of Tangerang City in 2014- 
2018. BPS Tangerang, 2015 About the Allotment of Regional Development Tangerang City. And BPS and Tangerang City Macro Economic Indicators, 2013. The Linkage of Regional Development Strategic Issues with Objectives: Tangerang City Regional Development in 20142018 and the Linkage of Regional Development Strategic Issues with Development Goals.

\section{Results and Discussion}

The volume of waste in the Tangerang Region amounts to 800 tons, while $12 \%$ of the amount of waste, around \pm 15 tons is in river bodies in 13 sub-districts in the City of Tangerang, which in August 2018 which is usually 14 tons to 17 tons, is exacerbated by the presence of waste which is brought from the surface water flow of Bogor Regency and South Tangerang can reach 1.5 tons. So that in August the amount of garbage in the river's surface water amounted to 18.5 tons from the original 14 tons in May - July 2018.

In Table 1 below, several sub-districts with a slope of $<1 \%$ are categorized as sloping, but have problems with drainage, which in turn results in flooding of the area. Subdistricts that frequently flood or surface water overflowed the most in Tangerang City, Karawaci District, Neglasari District and Priuk District.

Whereas in Tangerang Regency, which is the North Tangerang area, the subdistrict that often occurs overflowing Cisadane River's surface water, areas that were previously rice fields, such as Curug Subdistrict, Teluk Naga Subdistrict, Mekar Baru Subdistrict, Paku Haji Subdistrict, Sindang Jaya Subdistrict. For the Districts of Kosambi and the District of Legok due to the change of land function into area of property and factory.

And based on Table 1, all Tangerang areas experienced flooding of surface water, which eventually resulted in flooding. According to Heryani (2008) [6], contamination by organic or inorganic waste causes changes in the physical, chemical, and biological conditions of river ecosystems. Because waste is composed of various components, such as waste that is easily biodegradable and difficult to decompose such as leaves (wet garbage), plastic waste, cans and styrofoam (dry waste).

The existing waste will change the structure and function of the river, so that it can reduce the carrying capacity and carrying capacity, and cause ecological disruption. Since the normalization of the Cisadane River on March 26, 2017, the flow of water has become smoother, less flooding in the flood-affected areas. Compared to previous problems, there were various problems caused by the high volume of garbage entering the Cisadane River body, especially 
in areas in Tangerang City so that the flow capacity of the flow decreased. It is feared that the reduced flow capacity will disrupt its original function, which is aimed at flood control and provision of raw water from the PDAM.

Thus the river normalization is held in addition to dealing with flood management, also for the arrangement of the Cisadane River border, situ revitalization, and raw water supply. The impact of normalization has re-functioning the Pasar Baru Dam of the Cisadane river located in Koang Jaya Sub-district, Karawaci sub-district, Tangerang City. Based on the data the dam was built during the Dutch colonial period around 1930 [6] [8] [4]. The initial purpose of the construction of the Cisadane irrigation dam, which was equipped with 10 weirs width $10 \mathrm{~m}$, two intake gates and two doorvoer / drain gates, there were 5 units of propulsion engines, with one unit moving two weirs, the length of the channel $214,978 \mathrm{~m}$ consisting of main channel $(84,585$ $\mathrm{m}$ '), secondary channel (103,393 m'), drainage channel (27,000 m '), which are used to irrigate rice fields with an area of 40,663 hectares, irrigating the areas of Tangerang Regency, Tangerang City, Serang Regency and DKI Jakarta.

Almost at the same time as the construction of the Cisadane irrigation dam, approximately one km away was the Scott Slauis Aflat Slauis building or the Sewan Dam, which had the function of pouring water into DKI Jakarta, through the MookerVaart River. With the existence of dams, the working pattern of irrigation should be clear, and landfill is clear in which direction the waste will go with the flow, and gather on the surface of the Cisadane river. But because of the long river there are residential settlements, which are accustomed to using Cisadane surface water for bathing, washing and toileting (MCK), and with the culture of bad habits of the community, namely littering causes garbage pollution, which is the waste disposal from the community can never be completely resolved, and the river can never be clean of rubbish.

The type of waste, which is found on Cisadane's surface water bodies is in the form of paper, plastic, beverage bottles, household utensils, food wrapping mattresses, food scraps and leaves, twigs or stems from plants. It is the biggest contributor to household waste that can never be controlled, the behavior of the surrounding community who live on the banks of the Cisadane River are not proactively ecologically proactive for their environment, moreover the authorities here are also passive in action. This is evident from several interviews with officers in the field, showing that garbage cleaners in the Cisadane River cannot act, when a community violates regulations, such as dumping garbage directly into 
water bodies. Likewise, the results of interviews with several people who live on the banks of the river, who behave indulgently with the condition of the waterway.

According to Lerner and Holt (2012), the community is the highest actor (ultimate beneficiary) in terms of river use [9]. In regional and city planning, river planning and structuring is always trying to be able to integrate the lives of urban communities with their rivers. The relationship between the river and the city is a step that must be studied because between behavior (culture) with the restoration step is often not integrated and cause conflict [11].

Table 1. Administrative City / Regency: Tangerang City and Tangerang Regency: Districts and Sub-Districts / Villages through which the river is flooded and its existing conditions.[4],[8] 


\begin{tabular}{|c|c|c|c|c|c|c|c|c|c|}
\hline \multirow[t]{2}{*}{ No } & \multirow[t]{2}{*}{ District } & \multirow[t]{2}{*}{$\sum_{\mathrm{K} / \mathrm{D}}$} & \multirow[t]{2}{*}{ Region } & \multicolumn{3}{|c|}{$\begin{array}{l}\text { River } \\
\text { crossing }\end{array}$} & \multirow[t]{2}{*}{ Slope } & \multicolumn{2}{|c|}{ Flood event } \\
\hline & & & & 1 & 2 & 3 & & Few & Often \\
\hline \multicolumn{2}{|c|}{ Kota Tangerang } & & & & & & & & \\
\hline 1. & Batu Ceper & 7 & $\begin{array}{l}\text { Tangerang } \\
\text { City }\end{array}$ & $\sqrt{ }$ & & & $\begin{array}{c}< \\
2 \%)\end{array}$ & $\sqrt{ }$ & \\
\hline 2. & Benda & 5 & $\begin{array}{c}\text { Tangerang } \\
\text { City }\end{array}$ & $\sqrt{ }$ & & & $\begin{array}{c}< \\
2 \%)\end{array}$ & $\sqrt{ }$ & \\
\hline 3. & Cibodas & 6 & $\begin{array}{c}\text { Tangerang } \\
\text { City }\end{array}$ & $\sqrt{ }$ & & & $\begin{array}{c}< \\
2 \%)\end{array}$ & $\sqrt{ }$ & \\
\hline 4. & Ciledug & 8 & $\begin{array}{c}\text { Tangerang } \\
\text { City }\end{array}$ & $\sqrt{ }$ & & & $\begin{array}{c}< \\
2 \%)\end{array}$ & $\sqrt{ }$ & \\
\hline 5. & Cipondoh & 10 & $\begin{array}{c}\text { Tangerang } \\
\text { City }\end{array}$ & $\sqrt{ }$ & & & $\begin{array}{c}< \\
2 \%)\end{array}$ & $\sqrt{ }$ & \\
\hline 6. & Jatiuwung & 6 & $\begin{array}{c}\text { Tangerang } \\
\text { City }\end{array}$ & $\sqrt{ }$ & & & $\begin{array}{c}< \\
2 \%)\end{array}$ & $\sqrt{ }$ & \\
\hline 7. & Karang Tengah & 7 & $\begin{array}{c}\text { Tangerang } \\
\text { City }\end{array}$ & $\sqrt{ }$ & & & $\begin{array}{c}< \\
2 \%)\end{array}$ & & \\
\hline 8. & Karawaci & 16 & $\begin{array}{c}\text { Tangerang } \\
\text { City }\end{array}$ & $\sqrt{ }$ & & & $\begin{array}{c}< \\
2 \%)\end{array}$ & & $\sqrt{ }$ \\
\hline 9. & Larangan & 8 & $\begin{array}{c}\text { Tangerang } \\
\text { City }\end{array}$ & $\sqrt{ }$ & & & $\begin{array}{c}< \\
2 \%)\end{array}$ & $\sqrt{ }$ & \\
\hline 10. & Priuk & 5 & $\begin{array}{c}\text { Tangerang } \\
\text { City }\end{array}$ & $\sqrt{ }$ & & & $\begin{array}{c}< \\
1 \%)\end{array}$ & & $\sqrt{ }$ \\
\hline 11 & Neglasari & 7 & $\begin{array}{c}\text { Tangerang } \\
\text { City }\end{array}$ & $\sqrt{ }$ & & & $\begin{array}{c}< \\
1 \%)\end{array}$ & & $\sqrt{ }$ \\
\hline 12. & Pinang/ Penang & 11 & $\begin{array}{l}\text { Tangerang } \\
\text { City }\end{array}$ & $\sqrt{ }$ & & & $\begin{array}{c}< \\
2 \%)\end{array}$ & $\sqrt{ }$ & \\
\hline 13. & Tangerang & 8 & $\begin{array}{l}\text { Tangerang } \\
\text { City }\end{array}$ & $\sqrt{ }$ & & & $\begin{array}{c}< \\
2 \%)\end{array}$ & $\sqrt{ }$ & \\
\hline Total & 13 & 104 & & & & & & & \\
\hline \multicolumn{10}{|c|}{ Kabupaten Tangerang } \\
\hline 1 & Balaraja & 9 & $\begin{array}{c}\text { West } \\
\text { Tangerang }\end{array}$ & & & & $\begin{array}{c}< \\
2 \%)\end{array}$ & & \\
\hline 2. & Cikupa & 14 & $\begin{array}{c}\text { South } \\
\text { Tangerang }\end{array}$ & & & $\sqrt{ }$ & $\begin{array}{c}< \\
2 \%)\end{array}$ & & \\
\hline 3. & Cisauk & 6 & $\begin{array}{l}\text { South } \\
\text { Tangerang }\end{array}$ & & & $\sqrt{ }$ & $\begin{array}{c}< \\
2 \%)\end{array}$ & $\sqrt{ }$ & \\
\hline 4. & Cisoka & 10 & $\begin{array}{l}\text { South } \\
\text { Tangerang }\end{array}$ & & & $\sqrt{ }$ & $\begin{array}{c}< \\
2 \%)\end{array}$ & $\sqrt{ }$ & \\
\hline 5. & Curug & 7 & $\begin{array}{c}\text { South } \\
\text { Tangerang }\end{array}$ & $\sqrt{ }$ & $\sqrt{ }$ & & $\begin{array}{c}< \\
1 \%)\end{array}$ & & $\sqrt{ }$ \\
\hline 6. & Gunung Kaler & 8 & $\begin{array}{c}\text { South } \\
\text { Tangerang }\end{array}$ & & $\sqrt{ }$ & & $\begin{array}{c}< \\
2 \%)\end{array}$ & & \\
\hline 7. & Jambe & 10 & $\begin{array}{c}\text { South } \\
\text { Tangerang }\end{array}$ & & & & $\begin{array}{c}< \\
2 \%)\end{array}$ & $\sqrt{ }$ & \\
\hline 8. & Jayanti & 8 & $\begin{array}{l}\text { South } \\
\text { Tangerang }\end{array}$ & & & & $\begin{array}{c}< \\
2 \%)\end{array}$ & $\sqrt{ }$ & \\
\hline 9. & Kelapa Dua & 6 & $\begin{array}{l}\text { South } \\
\text { Tangerang }\end{array}$ & & & & $\begin{array}{c}< \\
2 \%)\end{array}$ & $\sqrt{ }$ & \\
\hline 10. & Kemiri & 7 & $\begin{array}{l}\text { North } \\
\text { Tangerang }\end{array}$ & & & & $\begin{array}{c}< \\
2 \%)\end{array}$ & $\sqrt{ }$ & \\
\hline
\end{tabular}




\begin{tabular}{|c|c|c|c|c|c|c|c|c|}
\hline 11. & Kosambi & 10 & $\begin{array}{c}\text { North } \\
\text { Tangerang }\end{array}$ & $\sqrt{ }$ & $\sqrt{ }$ & $\begin{array}{c}< \\
1 \%)\end{array}$ & & $\sqrt{ }$ \\
\hline \multirow[t]{2}{*}{12.} & Kresek & 10 & North & & $\sqrt{ }$ & $<$ & $\sqrt{ }$ & \\
\hline & & & Tangerang & & & $2 \%)$ & & \\
\hline \multirow[t]{2}{*}{13.} & Kronjo & 11 & North & & & $<$ & $\sqrt{ }$ & \\
\hline & & & Tangerang & & & $2 \%)$ & & \\
\hline \multirow[t]{2}{*}{14.} & Legok & 11 & South & $\sqrt{ }$ & $\sqrt{ }$ & $<$ & & $\sqrt{ }$ \\
\hline & & & Tangerang & & & $1 \%)$ & & \\
\hline \multirow[t]{2}{*}{15.} & Mauk & 12 & North & $\sqrt{ }$ & & $<$ & $\sqrt{ }$ & \\
\hline & & & Tangerang & & & $2 \%)$ & & \\
\hline \multirow[t]{2}{*}{16.} & Mekar Baru & 7 & North & $\sqrt{ }$ & & $<$ & & $\sqrt{ }$ \\
\hline & & & Tangerang & & & $1 \%)$ & & \\
\hline \multirow[t]{2}{*}{17.} & Pagedangan & 11 & North & & & $<$ & $\sqrt{ }$ & \\
\hline & & & Tangerang & & & $2 \%)$ & & \\
\hline \multirow{2}{*}{18.} & Paku Haji & 14 & North & $\sqrt{ }$ & & $<$ & & $\sqrt{ }$ \\
\hline & & & Tangerang & & & $1 \%)$ & & \\
\hline \multirow[t]{2}{*}{19.} & Panongan & 8 & North & & $\sqrt{ }$ & $<$ & $\sqrt{ }$ & \\
\hline & & & Tangerang & & & $2 \%)$ & & \\
\hline \multirow[t]{2}{*}{20.} & Pasar Kamis & 9 & North & & & $<$ & $\sqrt{ }$ & \\
\hline & & & Tangerang & & & $2 \%)$ & & \\
\hline \multirow[t]{2}{*}{21.} & Rajec & 13 & North & & & $<$ & $\sqrt{ }$ & \\
\hline & & & Tangerang & & & $2 \%)$ & & \\
\hline \multirow[t]{2}{*}{22.} & Sepatan & 8 & North & & & $<$ & $\sqrt{ }$ & \\
\hline & & & Tangerang & & & $2 \%)$ & & \\
\hline \multirow[t]{2}{*}{23.} & Sepatan Timur & 8 & North & & & $<$ & $\sqrt{ }$ & \\
\hline & & & Tangerang & & & $2 \%)$ & & \\
\hline \multirow[t]{2}{*}{24.} & Sindang Jaya & 7 & North & $\sqrt{ }$ & & $<$ & & $\sqrt{ }$ \\
\hline & & & Tangerang & & & $1 \%)$ & & \\
\hline \multirow[t]{2}{*}{25.} & Solear & 7 & North & & & $<$ & $\sqrt{ }$ & \\
\hline & & & Tangerang & & & $2 \%)$ & & \\
\hline \multirow[t]{2}{*}{26.} & Sukadiri & 8 & North & & & $<$ & $\sqrt{ }$ & \\
\hline & & & Tangerang & & & $2 \%)$ & & \\
\hline \multirow[t]{2}{*}{27.} & Sukamulya & 8 & North & & & $<$ & $\sqrt{ }$ & \\
\hline & & & Tangerang & & & $2 \%)$ & & \\
\hline \multirow[t]{4}{*}{28.} & Teluk Naga & 13 & North & & & $<$ & & $\sqrt{ }$ \\
\hline & & & Tangerang & & & $1 \%)$ & & \\
\hline & Tiga Raksa & 14 & West & & $\sqrt{ }$ & $<$ & $\sqrt{ }$ & \\
\hline & & & Tangerang & & & $2 \%)$ & & \\
\hline Total & 29 & 299 & & & & & & \\
\hline
\end{tabular}

Source: Processed from various sources (2018).

Note: River Crossing No-1 = S. Cisadane, No-2 = Cirarab River and No-3 = Cimanderi River

Based on the specifications of the Cisadane weir that serves to prevent the overflow of the Cisadane River's surface water, Tangerang City should never have flooded. But in reality some of the existing sub-districts such as Karawaci District, Neglasari District and Priuk District are always flooded. This condition is exacerbated during the rainy season, water discharge enters a critical level, because the water level reaches 11.70 meters from the normal limit of 12.50 meters 
[2]. Flood supply areas are usually upstream of the watershed, so changes in upstream land cover can cause a decrease in infiltration capacity and increased surface runoff [5]. Based on this, a lot of water supply must be managed as much as possible flowed into the ground (infiltration), because the pile of garbage in surface water that can cause flooding occurs in the Regency and City of Tangerang, because the area is mostly flat (slope $<2 \%$ ) and by closing paddy fields. The area included in the Cisadane watershed $(28,446$ ha or $18.78 \%$ ) is very vulnerable to flooding.

Because there is still a lot of garbage that clogs the drainage flow, it indicates that the drainage system in both districts is still not good. The community must routinely clean gutters in front of their houses because if it is not done it will cause drainage flow not smooth. This condition also contributed to siltation in the Cisadane River due to the abundance of deposition of organic matter (due to poor sanitation) and stagnant rubbish which made it a pile of sediment as high as 1.32 meters. River basin space currently only has an effective depth of 1.41 meters.

Table 2. Specifications of Cisadane Irrigation Weir to Prevent Overflow of the Cisadane River Surface Water.

\begin{tabular}{|c|c|c|c|c|c|}
\hline No. & Facilities & $\begin{array}{c}\sum \\
\text { (unit) }\end{array}$ & Purpose & Specifications & Explanation \\
\hline 1. & $\begin{array}{l}\text { Weir } \\
\text { door }\end{array}$ & 10 & $\begin{array}{l}\text { - diverting } \\
\text { water so that it } \\
\text { can flow into } \\
\text { the channel } \\
\text { and into the } \\
\text { fields for } \\
\text { irrigation } \\
\text { purposes. } \\
\text { - to raise the water } \\
\text { level so that it } \\
\text { can be flowed } \\
\text { gravity to where } \\
\text { it is needed }\end{array}$ & $\begin{array}{l}* 10 \mathrm{~m} \text { wide } \\
* \text { Long } \\
\text { * Normal discharge }-12.45 \\
\text { (upstream) } \\
\text { * Flood discharge } \\
\text { (downstream peil) } \\
\text { * Ready Conditions (peil } \\
+09.00 \text { to }+10.00 \\
* \text { Standby Conditions (peil } \\
+10.00 \text { to }+11.00 \text { ) } \\
* \text { Beware condition (peil + } \\
11.00 \text { to + } 12.00 \text { ) } \\
* \text { Peil Condition }>-12.50 \\
\text { Automatic alarm sounds }\end{array}$ & $\begin{array}{l}\text { * Weir (Bangunan sadap) or } \\
\text { Weir (Diversion Structure) is a } \\
\text { building (complex of buildings) } \\
\text { across the river that serves to } \\
\text { increase the elevation of river } \\
\text { water. } \\
\text { * The definition of weir } \\
\text { according to the ARS Group, } \\
\text { 1982, Analysis of Wages and } \\
\text { BOW Materials (Burgerlijke } \\
\text { Openbare Werken), Bandung is } \\
\text { a water structure (and its } \\
\text { accessories) that is built across } \\
\text { the river or on a riverbank } \\
\text { *Current condition: } \\
\text {-Still works } \\
\text {-Still manual how it works }\end{array}$ \\
\hline 2. & $\begin{array}{l}\text { Intake } \\
\text { door }\end{array}$ & 2 & 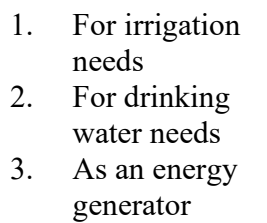 & $\begin{array}{l}* \text { The maximum surface } \\
\text { water discharge is } 2,200 \\
\text { M3 / sec }\end{array}$ & $\begin{array}{l}\text { * The intake or gate functions } \\
\text { to regulate the amount of water } \\
\text { entering, which will be flowed } \\
\text { into the irrigation channel } \\
\text { through a mud bag }\end{array}$ \\
\hline
\end{tabular}




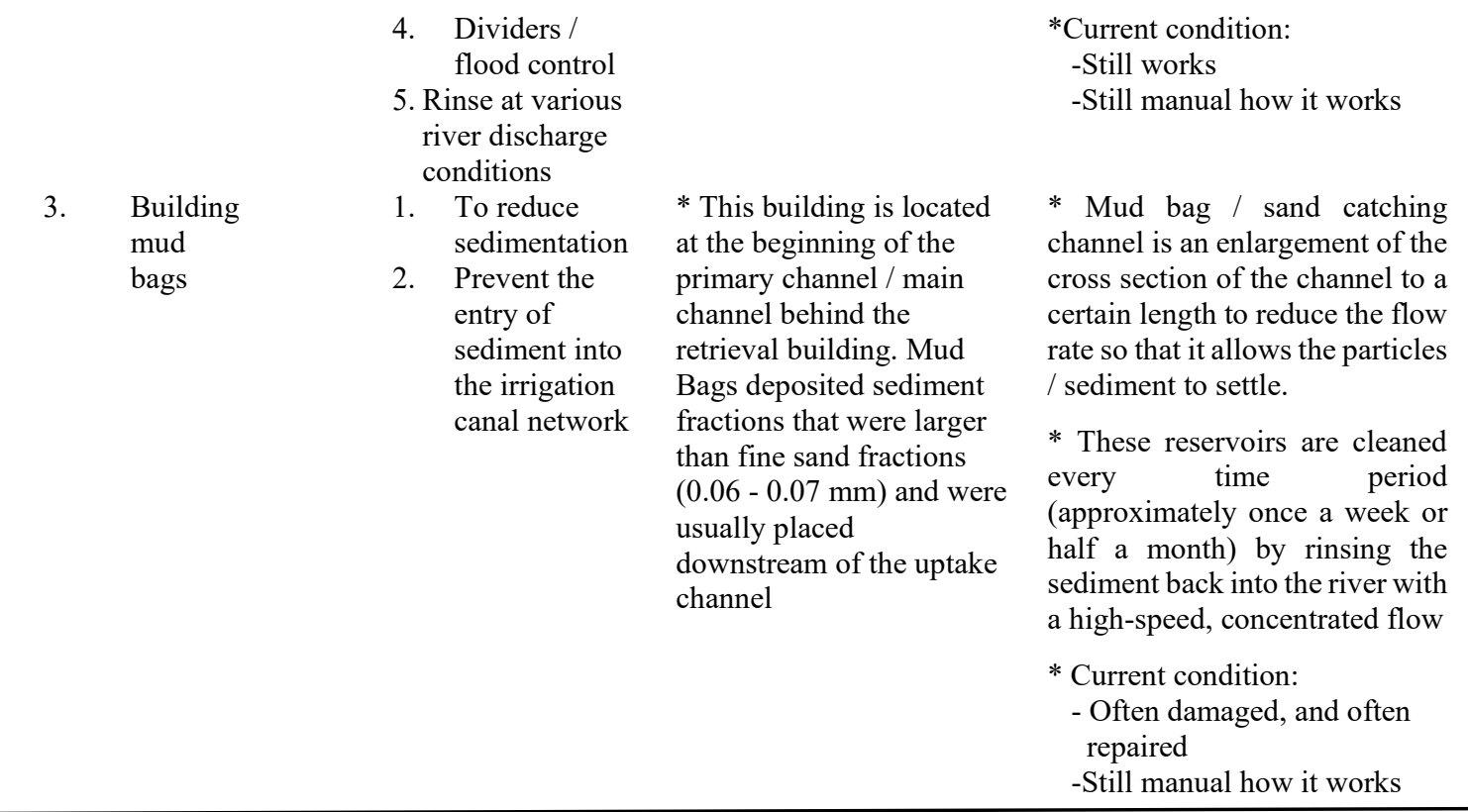

Source: Processed from various sources (2018).

Based on data in BPS Tangerang in 2015, Tangerang Regency has land allotments such as, $56.3 \%$ settlements $31.7 \%$, ponds / paddy fields $11 \%$ and airports $1 \%$. All four land uses are all vulnerable to flooding, both because the surface of the land becomes impermeable or saturated with water. While the City of Tangerang, with an area of 8504.90 ha, is also very vulnerable to flood hazards, with an area of $61 \%$ are settlements, $18 \%$ rice fields, $20 \%$ ponds and $1 \%$ airport. With the designation and development of residential expansion compared to other allotments, there is an imbalance in the ecological balance of the Tangerang Region, so that it can be understood if floods always occur in the City and Regency of Tangerang. With the condition of the community always throwing household garbage into the water body, while there is not enough landfills.

The Final Waste Disposal Site (TPA) in the Tangerang Region.

1. Jatiwaringin Landfill, Mauk District, Tangerang Regency

Waste generated by 3 million inhabitants in Tangerang Regency reaches 580 M3.

Furthermore, the garbage is transported to the Final Disposal Site (TPA) in Jatiwaringin 
Village, Mauk District. However, only half of that amount can be transported daily to the landfill. The Jatiwaringin TPA with an area of 20 ha is a final landfill that holds rubbish from all of Tangerang Regency. The Jatiwaringin Final Disposal Site (TPA) still uses a system of piling garbage or open dumpling. In other words, the rubbish is only stored, piled up, arranged, and tidied there. That causes disruption to the comfort of the population in the Jatiwaringin Village.

\section{Cipeucang TPA in Setu Subdistrict, South Tangerang}

TPST are located in District Tigaraksa, Pasar Thursday, Cikupa, Sepatan, Panongan, Mauk, Pagedangan, and Legok. Every day waste production in the region reaches 130 tons, but only half of it is able to be transported to landfill due to fleet limitations. Because all this time, garbage has only been transported around $50 \%$ to the final landfill (TPA) in Cipeucang, Setu District, in a day, garbage entering the Cipeucang TPA is around $600 \mathrm{M} 3$ meters with a weight reaching 130 tons. From the total weight of waste calculated per day, if divided by the total population of South Tangerang, which reaches 1.4 million people, the garbage per household can reach three kilograms per day. Cipeucang TPS has a 15 hectare waste collection area. However, there are currently only around 4.4 hectares that can be used. Of the 130 tons that were raised in half were scattered, because the pattern of moving from the residents' garbage transport carts to the garbage collection is still the traditional way, as a result there are some volumes that are not transported from the garbage cart at the Rawa Kucing landfill, Neglasari District Tangerang Regency.

3. TPA Rawa Kucing uses an open dumping disposal system, and has an area of 8 Ha, which is used only $6 \mathrm{Ha}$, while the rest is still not used. The Rawa Kucing TPA works well even though it is sometimes overloaded. Estimated 4508 M3, per day the volume entering the river. But the pattern of appointment and distribution by truck to the final shelter is more or less scattered and eventually some will enter the waterway by $20 \%$. The condition of the land is very narrow and open there is a possibility of wind and rain exposure also contributes to the entry of garbage into the water body. Waste management in the landfill also makes the odor odor not pierce the nose. This does not take into account the time of heavy rain which results in a flow that carries garbage from the drainage channel and from the upstream direction of Cisadane. 


\section{Conclusions and Suggestions}

This research can answer in general, that the attitudes of the people who live on the banks of the Cisadane river, are still less concerned with their environment, so that the harmony of attitudes with the sustainability of the river's ecological functions is still very low. Based on the discussion above, it can be concluded that the entry of garbage into the Cisadane River has caused:

1. Siltation on the banks, bodies and banks of the Cisadane River.

2. In certain areas Tangerang City Region which is vulnerable to flooding consists of:

Karawaci

Subdistrict, Priuk Subdistrict and Neglasari Subdistrict. And in certain areas Tangerang District Region that is vulnerable to flooding consists of: Curug District, Kosambi District, Mekar Kondang District, Paku Haji District, Sindang Jaya District, Teluk Naga District.

3. Disrupting the function of the Cisadane River as flood control, and providing raw water for the entire Tangerang Region.

\section{Suggestion}

1. Routine sediment dredging is needed to increase the Cisadane River water flow to prevent siltation.

2. Need to make a means of capturing waste in the Cisadane River, in order to facilitate the transportation of incoming garbage.

3. Invite citizens to participate actively, to help keep the river clean, Grow a sense of belonging and love a clean and healthy environment.

\section{References}

[1] Arikunto, Suharsimi.: Prosedur Penelitian, suatu pendekatan praktik. Rineka Cipta, Jakarta (2014)

[2] Anon.:Peraturan Pemerintah Republik Indonesia No. 38/2011 Tentang Sungai, Indonesia (2011)

[3] BPS Tangerang.:Tentang Peruntukan Pembangunan Daerah Kota Tangerang (2015)

[4] BPS dan Indikator Makro Ekonomi Kota Tangerang.: Tentang Keterkaitan Isu Strategis

Pembangunan Daerah dengan Tujuan, Pembangunan Daerah Kota Tangerang Tahun 2014-2018 dan

Keterkaitan Isu StrategisPembangunan Daerah dengan Sasaran, Pembangunan Daerah Kota

Tangerang Tahun 2014-2018, Tangerang (2013) 
[5] Darmakusuma Darmanto, Sudarmadji.: Pengelolaan Sungai Berbasis Masyarakat Lokal Di Daerah Lereng Selatan Gunung Merapi. Jurnal Manusia Dan Lingkungan, Vol. 20, No. 2, Hal 230.

Diakses online Tanggal 27 November 2019 Pukul 20.30 WIB (2013)

[6] Daryanto dan Agung Suprihatin.: Pengantar Pendidikan Lingkungan Hidup. Gava Media, Yogyakarta (2014)

[7] Heryani, N.: Sistem pemanenan air hujan (rainwater catchment systems): dalam upaya pengelolaan banjir di daerah perkotaan. https://bebasbanjir2025.wordpress.com/ diakses online pada Tanggal 8 September 2019, Pukul 20.35 WIB.(2008)

[8] https://www.kabar-banten.com/sampah-masih-jadi-masalah-utama-di-kabupaten-tangerang/ diakses online pada Tanggal 27 November 2019, Pukul 10.15 WIB.(2019)

[9] Lerner, David N, Alison Holt.: “How Should We Manage Urban River Corridors?” dalam Jurnal Procedia Environmental Sciences. Vol 13. Hlm. 721-729. Elsevier B.V, Amsterdam (2013)

[10] Marans, Roberts W.: "Quality of Urban Life Studies: An Overview and Implications for Environment- Behaviour Research," dalam Jurnal Procedia: Social and Behavioral Sciences. Vol. 35.hlm 9-22. Elsevier B.V, Amsterdam (2012)

[11] May, Racher.: "Connectivity” in Urban Rivers: Conflicts and Convergence Between Ecology and Design," dalam Jurnal Technology in Society. Vol. 28. Hlm. 477-488. Elsevier B.V , Amsterdam: (2006)

[12] Pakpour AH, Zeidi IM, Emamjomeh MM, Asefzadeh S, Pearson H. Household waste behaviours among a community sample in Iran: An application of the theory of planned behaviour. Waste management.: Jun 1;34(6):980-6 (2014)

[13] Peraturan Daerah Kota Tangerang No. 10 Tahun 2014 Tentang Rencana pembangunan Jangka Menengah Daerah Kota Tangerang Tahun 2014-2018 (2014)

[14] Peraturan Pemerintah Nomor 38 Tahun 2011 Tentang Sungai. Jakarta, (2011) 